\title{
THREE YEAR SEROEPIDEMIOLOGICAL STUDY OF VARICELLA-ZOSTER VIRUS IN SÃO PAULO, BRAZIL
}

\author{
Ana Lúcia Frugis YU(1), Jane Margarete COSTA(2), Marcos AMAKU(1), Cláudio Sérgio PANNUTI(2), Vanda Akico Ueda Fick de SOUZA(2),
} Dirce Maria Trevisan ZANETTA(1), Marcelo Nascimento BURATTINI(1), Eduardo MASSAD(1) \& Raymundo Soares AZEVEDO(1)

\begin{abstract}
SUMMARY
A serosurvey of varicella has been carried out in children attending the public school network of São Paulo city, Brazil, from 1992 to 1994. This study was performed in order to establish the age related prevalence of antibodies against varicella-zoster virus (VZV) and its age specific transmission dynamics pattern in these children. Among 2500 schools in the city of São Paulo public network, 304 were randomly selected; 7 children of a given age (ranging from 1 to 15 years) were randomly selected in each school, and blood samples were obtained by fingerprick into filter paper. Blood eluates were analyzed for the presence of antibodies to VZV by ELISA. Proportion of seropositivity were calculated for each age group. Samples consisted of 1768 individuals in 1992, 1758 in 1993, and 1817 in 1994, resulting in 5343 eluates. A high proportion of seropositive children from 1 to 3 years of age was observed, ascending until 10 years of age and reaching a plateau around $90 \%$ afterwards. VZV transmission in this community was similar along the three years of the study. In children attending public schools in the city of São Paulo, contact with VZV occurs in early childhood. If immunization against VZV is considered it should be introduced as soon as possible.
\end{abstract}

KEYWORDS: Varicella; Seroprevalence; Vaccination, São Paulo, Brazil.

\section{INTRODUCTION}

Varicella, the primary varicella-zoster virus infection, has long been considered a benign, self-limited and inevitable disease of childhood. Every individual is virtually infected by adulthood ${ }^{1,11,15}$. However, varicella can cause mild and unconfortable symptoms, and it can be especially severe in neonates, adults and immunocompromised patients ${ }^{10}$. Varicella presents a social-economic related cost, including direct medical costs (care clinic visits, medications, hospitalization due to complications), and indirect costs, related to reduced productivity associated with caregivers who stay off to care for infected children ${ }^{8,11}$. The epidemiology of varicella may be measured from seroprevalence studies or from reported cases in general practice. Serologic surveys has the advantages of being more specific, sensitive and capable of defining viral circulation accurately 9 .

In temperate countries varicella is a pre-school and school aged children disease, and around $90 \%$ of people will contract varicella before 20 years old. There was evidence of an increased incidence of varicella in children under 5 years old during the last decade, associated with a significant increase of the number of children under 5 who attended nursery or day care centers over this period ${ }^{7,15}$.

In tropical countries, varicella infection is beloved to occur later, with mean age of infection over 20 years of age, reaching a seroprevalence peak in adults over 40 years of age. People from tropical climates are considered of high-risk group for acquisition of varicella when they emigrate to countries of high VZV endemicity, influencing its epidemiology ${ }^{15}$.

A safe and protective live attenuated virus varicella vaccine was developed in Japan in the 1970's, allowing varicella prevention in healthy children. The varicella vaccine is licensed in some countries for routine immunization ${ }^{14}$.

Varicella is not a notifiable disease in Brazil, which makes its prevalence difficult to be estimated. On this background, the aim of this study was to identify the age-related seroprofile of the VZV and the pattern of the varicella transmission dynamics in order to help designing future intervention strategies in São Paulo city, Brazil.

\section{MATERIAL AND METHODS}

\section{Population}

São Paulo city is the capital of the State of São Paulo, Brazil. It is crossed by the Tropic of Capricorn, located in the southeast Brazil, with about 10 million inhabitants, $97 \%$ of them living in the urban area ${ }^{12}$. The Public Education network of São Paulo is comprised by 2500 


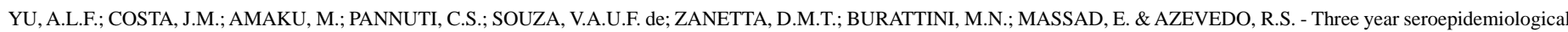
study of varicella-zoster virus in São Paulo, Brazil. Rev. Inst. Med. trop. S. Paulo, 42(3):125-128, 2000.

schools, including nurseries, kindergartens and first grade schools, corresponding to a school population of about 2 million children. This study was carried out in the Public Education and Well Fare System of São Paulo by a random sampling selection of 304 schools. In each school, 7 children were chosen, age varying from 1 to 11 years old in 1992, and from 1 to 15 years old in 1993 and 1994, comprising a 3 year study in the same 304 sorted schools, but different children were selected each year. The sampling technique is described elsewhere?

\section{Serology}

Blood was taken by finger prick with Glucolet ${ }^{\mathrm{TM}}$ disposable lancet and collected into two $2.5 \mathrm{~cm}$ diameter circles of Whatman ${ }^{\circledR} \mathrm{N}^{\circ} .1$ filter paper.

Blood elution was made using $500 \mu \mathrm{L}$ of a phosphate buffered saline (PBS). Eluates were frozen and stored at $-20^{\circ} \mathrm{C}$, for 5,4 and 3 years according to the year of blood collection. The eluates were thawed for 12 hours in refrigerator before being tested.

The eluates were tested for specific IgG antibody against VZV using two different techniques, namely: an in-house ELISA technique as described elsewhere ${ }^{3}$ (2590 eluates) and a commercially available enzyme immunoassay of solid phase in microtiter strips (ELISA TEST-HRP, Hycor Biomedical GmbH, Kassel, Germany), (3145 eluates); 220 eluates were analysed by both methods.

\section{Data Analysis}

A database was created, recording identification and serological data of individuals. The agreement of the 2 different ELISA techniques was evaluated by Kappa analysis. Results were analyzed to determine the seropositive proportion by age, and the respective $95 \%$ confidence interval (exact binomial method) and $\chi^{2}$ test. A $p$ value $<0.05$ was considered significant.

\section{RESULTS}

The Kappa coefficient ranged from 0.65 to 0.72 in the 3 years of study and the techniques were considered concordant. A total of 5343 eluates were analyzed from the three years of study: 1768 in 1992, 1758 in 1993 and 1817 in 1994. The age distribution of seropositivity was analyzed. At one year of age about $40 \%$ of this population was seropositive (33\% for 1992, 48.5\% for 1993, 35\% for 1994). From 2 years of age onwards, there was an increase in seropositivity until 10 years of age. Afterwards, the seropositivity remained around $90 \%$. An unexpected decrease in seropositivity was observed in children 4 and 5 years old (Table 1 and Figure 1). The age interval from 7 to 10 and over 14 years old were condensed to 8.5 and 14.5 years old respectively for better data analysis.

There was a significant difference in seroprevalence when proportions obtained for each year and the total sample in some age classes of the

Table 1

Proportion of seropositive children by age and by year

\begin{tabular}{cccc}
\hline Age(years) & \multicolumn{3}{c}{1992} \\
\cline { 2 - 4 } & \multicolumn{3}{c}{ \% seropositives } \\
& sample size & 95\%CI \\
\hline 1 & 115 & 33 & $24.6-42.4$ \\
\hline 2 & 175 & 63.4 & $55.8-70.6$ \\
\hline 3 & 185 & 73.5 & $66.5-79.7$ \\
\hline 4 & 154 & 65.6 & $57.5-73$ \\
\hline 5 & 192 & 58.9 & $51.5-65.9$ \\
\hline 6 & 185 & 71.4 & $64.3-77.7$ \\
\hline 8.5 & 742 & 80.6 & $77.5-83.3$ \\
\hline 11 & 20 & 85 & $62.1-96.8$ \\
\hline
\end{tabular}

12

\begin{tabular}{ccc}
\multicolumn{3}{c}{1993} \\
\hline \multicolumn{3}{c}{ \% seropositives } \\
sample size & \multicolumn{2}{c}{ 95\%CI } \\
\hline 134 & 48.5 & $39.8-57.3$ \\
\hline 187 & 66.8 & $59.6-73.5$ \\
\hline 192 & 82.8 & $76.7-87.9$ \\
\hline 136 & 74.3 & $66.1-81.4$ \\
\hline 202 & 75.2 & $68.7-81$ \\
\hline 141 & 82.3 & $74.9-88.2$ \\
\hline 119 & 85.7 & $78.1-91.5$ \\
\hline 179 & 93.9 & $89.3-96.9$ \\
\hline 181 & 93.4 & $88.7-96.5$ \\
\hline 150 & 90 & $84-94.3$ \\
\hline 137 & 89 & $82.6-93.7$ \\
\hline $95 \%=$ Confidence interval \\
\hline
\end{tabular}

\begin{tabular}{ccc}
\multicolumn{3}{c}{1994} \\
\hline \multicolumn{3}{c}{ \% seropositives } \\
sample size & \multicolumn{1}{c}{$95 \%$ CI } \\
\hline 180 & 35 & $28.1-42.4$ \\
\hline 157 & 60.5 & $52.4-68.2$ \\
\hline 153 & 71.2 & $63.4-78.3$ \\
\hline 99 & 58.6 & $48.2-68.4$ \\
\hline 201 & 66.7 & $59.7-73.1$ \\
\hline 160 & 79.4 & $72.3-85.4$ \\
\hline 56 & 92.9 & $82.7-98$ \\
\hline 223 & 84.3 & $78.9-88.8$ \\
\hline 219 & 83.6 & $78-88.2$ \\
\hline 214 & 86.4 & $81.1-90.7$ \\
\hline 155 & 89 & $83-93.5$ \\
\hline
\end{tabular}

\section{3}

$\geq 14.5$ 


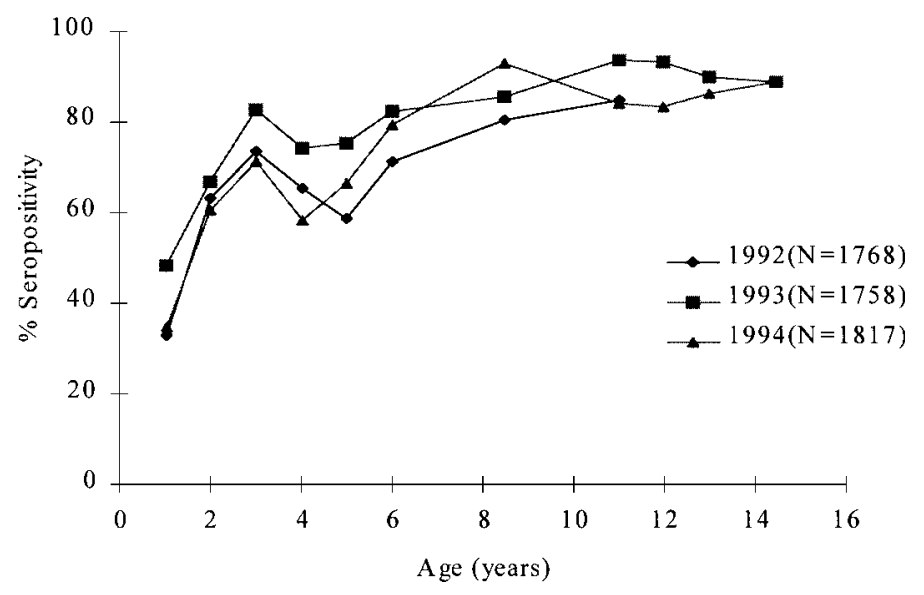

Fig. 1 - Proportion of seropositive children by age and by year.

studied period were compared (5 years in 1992; 1, 5, 11 and 12 years in 1993, and the age interval of 7 to 10 years in 1994).

\section{DISCUSSION}

A safe, immunogenic and efficaccious vaccine against varicella is currently available and approved for use in healthy children in some countries. The possibility of a widespread immunization with varicella vaccine is expected to change the epidemiology of the disease, causing a large reduction of primary cases. At the same time, it may lead to a shift to an older age distribution of the remaining cases ${ }^{7}$, where risk of complications is higher ${ }^{10,15}$. Characterization of the varicella prevalence profile in a non-vaccinated children population allows the estimation of the varicella transmission pattern. The recognition of the pattern combined with mathematical models, allows the design of intervention strategies possible. It is important to ascertain accurately the age specific incidence rates of varicella before widespread administration of the vaccine. A valid baseline data would allow early detection of shifts in incidence towards older age groups or specific population at risk of undercoverage ${ }^{5}$.

In temperate climate countries, varicella has been considered a preschool and school aged children disease with high incidence rates among children 5 to 9 years of age and 1 to 4 years of age ${ }^{15}$. With increasing number of young children gathering school, the average age incidence of the disease has decreased in the nineties. Seronegativity rates are higher in people raised in rural areas and in tropical zones ${ }^{2,13}$, where varicella occurs among older persons $\mathrm{s}^{6,15}$. However, an increase in the number of susceptible adults in temperate countries has been observed probably related to the high number of immigrants coming from rural areas of developing countries ${ }^{4}$.

São Paulo city is located in a tropical area, tempered by the altitude. The occurrence of seropositivity was observed since 1 year of age with high proportions of seropositives close to 3 years of age, related to children attending all-day nurseries or day-care setting, providing great opportunity for close exposure and efficient transmission of VZV in the very young children. The observed decrease in seropositivity in children
4 and 5 years old may have occurred due to different degrees of sociability. This age-class represented children starting school at 4 years of age mixed with children coming from nurseries or day-cares. Also children from this age-class spend only one period of the day in school. These observations could be responsible for the decreased seropositivity at 4 years of age. The observed high seropositivity in 1993 could result from an increased number of cases in this period but we do not have informations about this possibility. The presence of low number of susceptibles in children over 10 years old was observed in the 3 years of the study.

These results will allow the development of a transmission model for varicella in São Paulo metropolitan area and the design of immunization strategies against varicella.

\section{CONCLUSION}

We observed a high proportion of seropositive children from 1 to 3 years of age among the school children enrolled in nurseries or day-care centers in São Paulo City. The seropositivity rose slowly until 10 years of age, when it reached a seroprevalence of $90 \%$.

These findings demonstrated that contact with VZV occurred early in childhood in this sample of school children of São Paulo. We should consider to introduce immunization against VZV as soon as possible.

\section{RESUMO}

\section{Três anos de estudo soroepidemiológico do vírus varicela-zoster em São Paulo, Brasil}

Um estudo sorológico para varicela foi realizado em crianças matriculadas na rede pública de ensino da cidade de São Paulo, Brasil, entre 1992 e 1994. O objetivo deste estudo foi determinar a soroprevalência idade-dependente de anticorpos contra o vírus varicelazoster (VVZ) e definir sua dinâmica de transmissão nestas crianças.

Foram selecionadas, ao acaso, 304 escolas entre os 2500 equipamentos da Rede Pública de Educação e Bem Estar Social na cidade de São Paulo; foram sorteadas em cada escola 7 crianças de determinada idade (de 1 a 15 anos), e o sangue colhido em papel de filtro. Os eluatos foram avaliados para anticorpos contra o vírus varicela zoster através de técnica de ELISA. A proporção de soropositivos para cada faixa etária foi calculada.

Foram obtidas 1768 amostras em 1992, 1758 em 1993 e 1817 em 1994, resultando em 5343 eluatos. Observou-se alta proporção de soropositivos no intervalo etário de 1 a 3 anos de idade, ascendendo até os 10 anos, mantendo-se ao redor de $90 \%$ a partir desta idade.

O padrão de transmissão do VVZ nesta comunidade é semelhante ao longo dos 3 anos estudados. Nas crianças frequentadoras das escolas públicas da cidade de São Paulo, o contacto com o VVZ ocorre no início da infância. Considerando-se a possibilidade de introdução da imunização contra a varicela, ela deve ocorrer o mais cedo possível. 


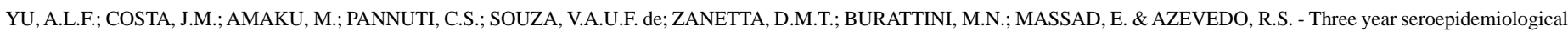
study of varicella-zoster virus in São Paulo, Brazil. Rev. Inst. Med. trop. S. Paulo, 42(3):125-128, 2000.

\section{REFERENCES}

1. ARBETER, A.M.; STARR, S.E.; PREBLUD, S.R. et al - Varicella vaccine trials in healthy children. Amer. J. Dis. Child., 138: 434-438, 1984.

2. ARBETER, A.M. - Clinical trials of varicella vaccine in healthy adolescents and adults. Infect. Dis. Clin. N. Amer., 10: 609-615, 1996.

3. CRISTÓFANI, L.M.; WEINBERG, A.; PEIXOTO, V. et al - Administration of live attenuated varicella vaccine to children with cancer before starting chemotherapy. Vaccine, 9: 873-876, 1991.

4. FAIRLEY, C. K. \& MILLER, E. - Varicella-zoster virus epidemiology. A changing scene? J. infect. Dis., 174(suppl. 3): S314-S319, 1996.

5. FINGER, R.; HUGHES, J.P.; MEADE, B.J.; PELLETIER, A.R. \& PALMER, C.T. Age-specific incidence of chickenpox. Publ. Hlth. Rep., 109: 750-755, 1994.

6. GARNETT, G.P.; COX, M.J.; BUNDY, D.A.P.; DIDIER, J.M. \& ST. CATHARINE, J. The age of infection with varicella-zoster virus in St. Lucia, West-Indies. Epidem. Infect., 110: 361-372, 1993.

7. HALLORAN, M.E. - Epidemiologic effects of varicella vaccination. Infect. Dis. Clin. N. Amer., 10: 631-655, 1996.
8. LIEU, T.; BLACK, S.B.; RIESER, N. et al. - The cost of childhood chickenpox: parents' perspective. Pediat. infect. Dis. J., 13: 173-177, 1994.

9. MASSAD, E.; AZEVEDO-NETO, R.S.; BURATTINI, M.N. et al. - Assessing the efficacy of a mixed vaccination strategy against rubella in São Paulo, Brazil. Int. J. Epidem., 24: 842-850, 1995.

10. PREBLUD, S.R. - Age-specific risks of varicella complications. Pediatrics, 68: 14-17, 1981.

11. PREBLUD, S.R. - Varicella: complications and costs. Pediatrics, 78: 728-735, 1986.

12. SEADE - State Data Analysis System Foundation, 1998. (URL: http://www.seade.gov.br).

13. STRUEWING, J.P.; KENNETH, C.H.; TUELLER, J.E. \& GRAY, G.C. - The risk of measles, mumps, and varicella among young adults: a serosurvey of US Navy and Marine Corps Recruits. Amer. J. publ. Hlth., 83: 1717-1720, 1993.

14. TAKAHASHI, M. - The varicella vaccine. Vaccine development. Infect. Dis. Clin. N Amer., 10: 469-488, 1996.

15. WHARTON, M. - The epidemiology of varicella-zoster virus infections. Infect. Dis. Clin. N. Amer., 10: 571-581, 1996.

Received: 09 November 1999 Accepted: 21 December 1999 